\title{
Degradation level of mangrove forest and its reduction strategies in Tabongo Village, Boalemo District, Gorontalo Province, Indonesia
}

\author{
ABUBAKAR SIDIK KATILI ${ }^{1,2, \boldsymbol{v}}$, MUSTAMIN IBRAHIM ${ }^{1,2}$, ZULIANTO ZAKARIA $^{1,2}$ \\ ${ }^{1}$ Department of Biology, Faculty of Mathematics and Natural Science, Universitas Negeri Gorontalo. Jl. Jenderal Sudirman No. 6, Gorontalo City 96128, \\ Gorontalo Province, Indonesia. "email: abubakarsidik@ung.ac.id; dikykatili@gmail.com \\ ${ }^{2}$ Center of Coastal Ecology Studies Based on Local Wisdom, Department of Biology, Universitas Negeri Gorontalo. J1. Jenderal Sudirman No. 6, \\ Gorontalo City 96128, Gorontalo Province, Indonesia
}

Manuscript received: 19 May 2017. Revision accepted: 11 June 2017

\begin{abstract}
Katili AS, Ibrahim M, Zakaria Z. 2017. Degradation level of mangrove forest and its reduction strategy in Tabongo Village, Boalemo District, Gorontalo Province, Indonesia. Asian J For 1: 18-22. Mangrove forest ecosystem plays a vital role in delivering various ecosystem services. Yet, many mangrove forests are deforested and degraded including in Indonesia. This research aimed to assess the degradation level of mangrove forests in Tabongo Village, Dulupi Sub-district, Boalemo District, Gorontalo Province, Indonesia and to develop strategy to reduce such degradation. Explorative survey was conducted to collect data using Point Quarter Centered Meter (PQCM) method while the data analysis was done with quantitative descriptive analysis. The degradation level of mangrove forests was analyzed by standard criteria of mangrove degradation prescribed by the government regulation. Results showed that there were four species of mangroves in the studied area namely Rhizophora apiculata Blume, Rhizophora mucronata Lamk., Ceriops tagal (Perr) C.B.Rob, and Bruguiera which included in the Rhizophoraceae family. Rhizophora apiculata had the highest IVI value at the stage of tree and sapling, while Rhizophora mucronata Lamk had the highest IVI value at the stage of seedling. The mangroves in Tabongo can be classified as dwarf forest type which was a typical mangrove found in low edges. The mangrove condition in the coastal area of Tabongo was categorized as degraded $\left(\mathrm{TNS}_{1}=210\right)$. The conservation strategy that could be implemented to recover the quality of mangrove areas includes (i) the assessment of the importance of the mangrove areas with regard to their ecological and economic value, (ii) quality improvement of mangrove habitat, (iii) educational approach by making the mangrove areas as learning media and source, and (iv) empowerment of people living around the mangrove areas.
\end{abstract}

Keywords: Coverage value, degradation, density, mangrove forest

\section{INTRODUCTION}

Coastal areas consist of several ecosystems, such as mangrove forests, beach vegetation, coral reefs and seagrass beds, some of which may occur simultaneously and interrelated each other. These ecosystems deliver various ecosystem services in terms of provisioning, regulating, cultural and supporting services. One role played in supporting service is these ecosystems serve as an important habitat for biodiversity. For example, mangrove forests and coral reef ecosystems serve as the breeding and feeding grounds for various marine organisms, including fishes from larvae to adulthood (Onrizal et al. 2009, 2017; Utina 2012).

Mangrove forest is a coastal wetland ecosystem located in the intertidal zone of the transition between marine and terrestrial realms. It is commonly situated in estuaries, deltas, creeks, lagoons and swamps especially in tropical and subtropical areas. Some experts define the term "mangrove" differently, but principally it refers to the same thing, i.e., mangroves are plants in tidal areas and live as communities. Arief (2003) stated that mangroves are halophytic vegetation or plants that have high adaptability to salinity and must live in saline environmental conditions, thus called obligate halophyte plants. Whereas Noor (2012) added that mangroves can also include distinctive littoral plant formations in tropical and subtropical sheltered beaches.

As one of the natural resources in coastal areas, mangrove forest community has various benefits in terms of socio-economic and ecological aspects. In socioeconomic, mangrove can produce timber and in some cases, mangrove forests are managed as recreation areas. Ecological functions include maintaining coastal stability, the habitat of birds and marine biotas (e.g., fish, shrimp), acting as genetic pools, and supporting the entire life system around it (Irwanto 2007).

Nowadays, there is an emerging concern that mangrove forests play a vital role in climate change mitigation. Ilmiliyana (2012) states that over the last decade $\mathrm{CO}_{2}$ emissions increased from 1,400 million tons per year to 2,900 million tons per year. This increase of $\mathrm{CO}_{2}$ in the atmosphere will trigger global climate change. According to Bismark et al. (2008), mangroves is the major absorber of carbon dioxide $\left(\mathrm{CO}_{2}\right)$ from the atmosphere. Donato et al. (2012) stated that mangroves are known to have high assimilation ability and $\mathrm{C}$ absorption rate. It is supported by research in 25 mangrove sites along the Indo-Pacific regions indicating that mangroves are one of the richest carbon forests in the tropics, containing about $1,023 \mathrm{Mg}$ of carbon per hectare which is far high compared to the average carbon stock of other forest types in the world. 
This certainly is related indirectly to the mangrove ecological function. Mangroves absorb some of the carbon in the form of $\mathrm{CO}_{2}$ and use it for the process of photosynthesis, while others remain in the atmosphere.

Despite their importance, mangrove forests are often destructed as the population increases and the need for economic development. As a result, a large area of mangroves has been declining over time including in Indonesia (Onrizal 2010; Ilman et al. 2016). Yet, the destruction of mangrove forests is still continuing these days, especially in the fishery sector by clearing mangrove forests for pond development (Pramudji 2000).

One of mangrove areas in Indonesia is located in the coastal area of Dulupi Sub-district, Boalemo District, Gorontalo Province. The mangrove ecosystem in this area continues to be under pressure due to various human activities including fish aquacultures, settlements and agriculture. These activities result in the deforestation and degradation of mangrove forests in Dulupi. One of the causes of mangrove loss was vegetation clearing to establish hatchery areas. In addition to deforestation, degradation occurs due to intensive utilization of mangrove wood for fuel and building materials. This study is aimed to assess the vegetation condition of mangrove forests in Dulupi Sub-district, Boalemo District, Gorontalo Province to provide insight on the degradation level of the forest. We expect the results of this study can be used as a baseline for future studies and monitoring to develop management and conservation strategies of the mangrove forest.

\section{MATERIALS AND METHODS}

The study was located in Tabongo Village, Dulupi Subdistrict, Boalemo District, Gorontalo Province, Indonesia (Figure 1). Tabongo Village has 178.67 ha mangrove area. Based on the report of environmental status of Gorontalo Province, in 2013 the degraded mangrove area in Dulupi Sub-district was $13.05 \mathrm{Ha}$, with $9.52 \mathrm{Ha}$ of the degraded mangrove was located in Dulupi Village and $3.53 \mathrm{Ha}$ in Tabongo Village.

Explorative survey method was used in this study. Data were collected in the form of primary data and secondary data. The primary data collection was done by identifying all mangrove species in the research site and measuring the mangrove density level using the Point-Centered Quarter Method (Figure 2), based on Dahdouh-Guebas and Koedam (2006). Importance Value Indices (IVI), Species Coverage $(\mathrm{Ci})$, and Relative of Species Coverage (RCi) were calculated for each stage of mangrove trees. The degradation level was assessed using the standard criteria of mangrove degradation prescribed by the Indonesian Ministry of Forestry (2005).

\section{RESULTS AND DISCUSSION}

\section{Results}

There were four species of mangrove found at the research location in Tabongo Village, Dulupi Sub-district, namely Rhizophora apiculata Blume, Rhizophora mucronata Lamk., Ceriops tagal (Perr) C.B.Rob, and Bruguiera gymnorrhiza. All of them were found in stages of tree, sapling, and seedling.

\section{Importance Value Index (IVI)}

At tree stage, Rhizophora apiculata had the highest IVI value $(49.55 \%)$ compared to all species, followed by Bruguiera gymnorrhiza (49.16\%) and Rhizophora mucronata Lamk (48.048\%). Ceriops tagal had the lowest IVI with $46.88 \%$.

The floristic composition based on IVI at sapling stage is similar to tree stage, where Rhizophora apiculata also had the highest IVI value (50.88\%), followed by Bruguiera gymnorrhiza (50.47\%) and Rhizophora mucronata $(49.87 \%)$. Ceriops tagal was also recorded as the lowest IVI (49.84\%). At the seedling stage, Rhizophora mucronata was recorded as species with the highest IVI $(81.30 \%)$, followed by Rhizophora apiculata $(73.65 \%)$ and Bruguiera gymnorrhiza (70.74\%). Similar to tree and sapling stage, Ceriops tagal had also the lowest IVI $(69.99 \%)$. Based on this result, the mangrove community in this area is typical of Rhizophora apiculata-Rhizophora mucronata vegetation.

Rhizophora apiculata and $R$. mucronata are known as the most important and widespread species of mangrove plants (Noor et al. 1999, Onrizal and Mansor 2016; Onrizal et al. 2017). The dominance of these two mangrove species can cover up to $90 \%$ of the vegetation growing in one location, and the optimal growth occurs in deeply flooded areas, as well as on humus-rich soil, and they also bloom throughout the year. The research conducted by Soeroyo and Achmad (2002) showed that species in Rhizophoraceae family dominated the front zone of mangrove forest in the region of Sulawesi. This is in line with the results of this research which found that these two species were the main vegetation in the mangroves in Dulupi Sub-district.

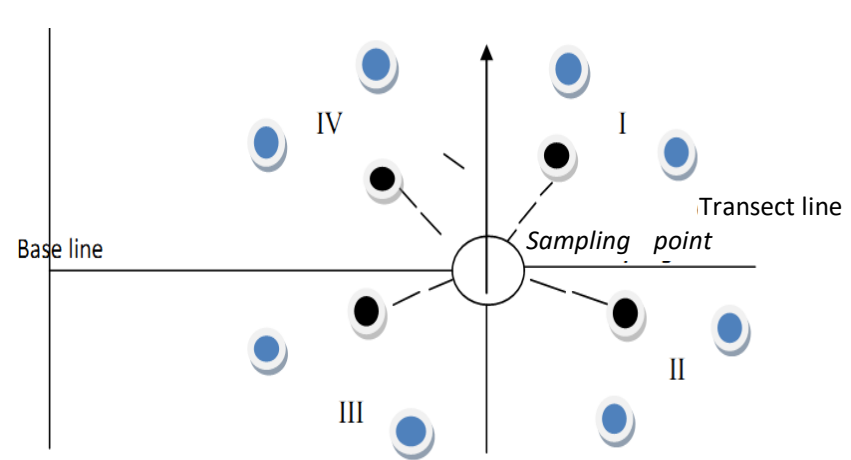

Figure 2. Point-centered quarter meter (PCQM) method used in this study 

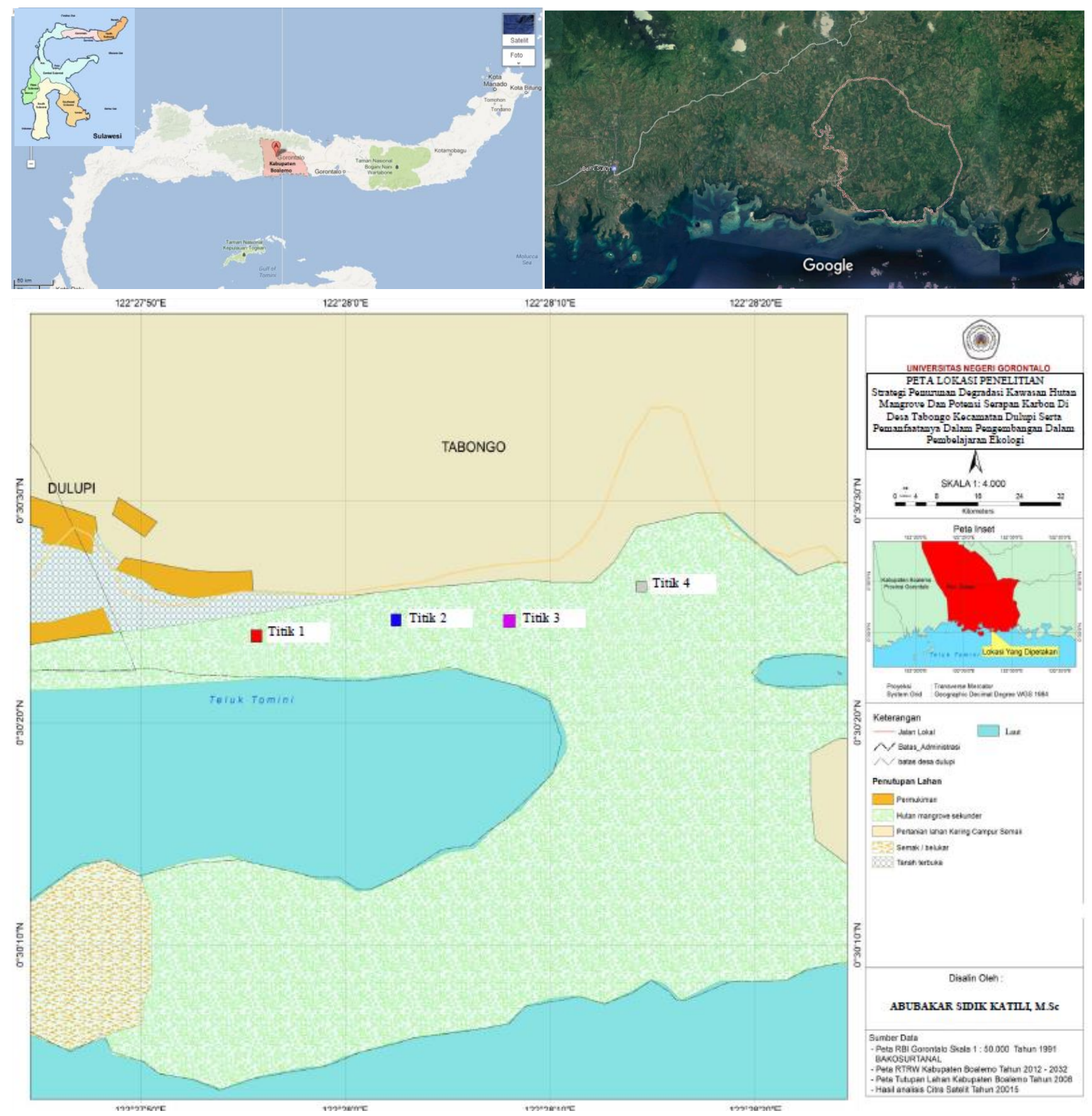

Figure 1. Research site in Tabongo Village, Boalemo District, Gorontalo Province, Indonesia

\section{Degradation level of mangrove}

Based on the calculation in tree and sapling stage, the mangrove condition at the studied area was categorized as degraded $\left(\mathrm{TNS}_{1}=210\right)$. However, based on land survey criteria it was categorized as not degraded $\left(\mathrm{TNS}_{2}=330\right)$. According to $\mathrm{MoF}$ (2005), the mangrove condition in the coastal area of Tabongo Village was categorized as good- very dense due to its density of $>1,500$ trees/ha for the sapling stage, while that for tree stage was $767.45 /$ ha which was categorized as degraded-sparse due to its density of < 1000 trees/ha. Based on the relative coverage values of each mangrove species, the condition was in the degraded criteria due to the coverage value of $<50 \% /$ ha. 


\section{Discussion}

The mangrove coverage at the research site showed significant degradation. This condition might be influenced by various human activities, such as the development of ponds for fish hatcheries, expansion of settlements, and timber cutting of mangroves for buildings and firewood. The degradation of mangrove coverage can cause mangrove litter production to decline and bring a negative impact on nutrient cycles in the region. According to Supriharyono (2007) the fertility of mangrove soils is affected by the decomposition of mangrove leaf litter and the level of sedimentation that occurred. This means that the lack of mangrove coverage also causes the sedimentation process of materials containing nutrients carried by the river flow to become less. While mangrove roots can retain the materials that enter the mangrove forest, the reduction in mangrove coverage causes less and even loss of mangrove roots, causing rich-nutrient materials in mangrove will be lowered.

The condition of mangrove forest in Tabongo Village, Boalemo was seriously damaged at the tree level. The same condition was also seen at the sapling level. Given the facts and conditions of existing mangrove area of Tabongo Village, Boalemo it can be predicted that after a period of time the ideal condition of mangroves in this area will continue to decrease significantly. Mitra (2013) stated that mangrove forests have immense ecological value. These forests protect and stabilize the coastal zone, fertilize the coastal waters with nutrients, yield commercial forest products, support coastal fisheries and provide a surprising genetic reservoir that are the sources of several bioactive substances and extracts having high medicinal values. Mitra (2013) said that these roles are influenced by three main factors, namely levels of water turbidity, tidal mixing, and the physical and structural complexity of the habitat.

Based on the results of this study, mitigation strategies to counterforce deforestation and degradation of mangrove forest in Tabongo Village is needed. This should be done by combining the ecological functions (conservation of mangrove forest) with the socio-economic interests of the people around the mangrove area. Thus, the strategies applied would be able to overcome the socio-economic problems of the surrounding community. One way of such strategies is by maintaining the natural conditions of mangroves and making its ecosystem as a buffer zone, while still involving the people around mangrove areas. Other ways to recover mangrove degradation can be done by growing mangrove seedlings and replanting them on the damaged area; introduction of various species of mangrove and its use through learning activities in schools around the mangrove area; and also more sustainable hatcheries management while considering the suitability of environmental factors such as the type of substrate and salinity.

In conclusion, mangrove vegetation in Tabongo was the type of Rhizophora apiculata-Rhizophora mucronata and dwarf forest type generally. This type was classified as a typical mangrove found in low edges. The mangrove in this area was in degraded condition. As such, mitigation strategies are required to restore the quality of the mangrove areas, including (i) the assessment of the importance of the mangrove areas with regard to their ecological and economic value, (ii) improving quality of mangrove habitat, (iii) educational approach by making the mangrove areas as learning media and source, and (iv) empowerment of people living in the mangrove areas.

\section{ACKNOWLEDGEMENTS}

Sincere gratitude to those who contributed and supported this research, i.e., Institute for Research and Community Services, Gorontalo State University, which funded this research; Department of Biology, Gorontalo State University, which provided administrative support for this research; Biology Laboratory, Gorontalo State University, which provided supporting data and references for this research, the government officials of Tabongo Village, Dulupi Sub-district, Boalemo District, Gorontalo Province, Indonesia.

\section{REFERENCES}

Arief A. 2003. Mangrove Functions and benefits. Kanisius. Jogjakarta. [Indonesian]

Bismark M, Subiandono E, Heriyanto NM. 2008. Diversity and Potential Types Carbon Content of Mangrove Forests in Subelen Siberut River, West Sumatera. Center of Forests Research and Conservation, Bogor. [Indonesian]

Dahdouh-Guebas F, Koedam N. 2006. Empirical estimate of the reliability of the use of the Point-Centred Quarter Method (PCQM): Solutions to ambiguous field situations and description of the PCQM+ protocol. For Ecol Manag 228 (1): 1-18. DOI: 10.1016/j.foreco.2005.10.076

Donato CD, Kauffman JB, Murdiyarso D, Kurnianto S, Stidham M, Kanninen M. 2012. Mangrove is one of the Richest Forests of Carbon in the Tropics. Cifor, Bogor. [Indonesian]

Giri C, Ochieng E, Tieszen LL, Zhu Z, Singh A, Loveland T, Duke N. 2011. Status and distribution of mangrove forests of the world using earth observation satellite data. Global Ecol Biogeogr 20 (1): 154159. DOI: $10.1111 / \mathrm{j} .1466-8238.2010 .00584 . x$.

Ilmiliyana A, Muryono M, Purnobasuki H. 2012. Estimation of Carbon Stok on Rhizophora stylosa stands at Camplong beach, SampangMadura. Department of Biology, Mathematics and Natural Science Faculty, Sepuluh November Technology Institute, Surabaya. [Indonesian]

Irwanto. 2007. Analysis of vegetation for management of protect area Marsegu Island, West Seram district. Maluku. Gadja Madah University. Yogyakarta. [Indonesian].

Environmental status report of Gorontalo Province, 2013. [Indonesian].

MoF. 2005. Pedoman Inventarisasi dan Identifikasi Lahan Kritis Mangrove. MoF, Jakarta. [Indonesian]

Mitra A. 2013. Sensitivity of Mangrove Ecosystem to Changing Climate. Springer, New Delhi.

Noor YR, Khazali M, Suryadiputra INN. 2012. Guidance introduction of mangrove in Indonesia. PHKA/WI-IP, Bogor.[Indonesian]

Onrizal. 2010. Change of mangrove forest coverage in east coastal area North Sumatra period 1977-2006. Jurnal Biologi Indonesia 6 (2): 163172. DOI: 10.14203/jbi.v6i2.3154. [Indonesian]

Onrizal, Ahmad AG, Mansor M. 2017. Assessment of Natural Regeneration of Mangrove Species at Tsunami Affected Areas in Indonesia and Malaysia. IOP Conference Series: Materials Science and Engineering $180 \quad(1)$ : 012045. DOI: $10.1088 / 1757$ 899X/180/1/012045.

Onrizal, Kusmana C, Mansor M. 2009. The effect of tsunami in 2004 on mangrove forests, Nias Island, Indonesia. Wetland Sci 7 (2): 130-134.

Pramudji. 2000. The mangrove forest in Indonesia: The role of mangrove, problems, and management. Oseana 25 (1): 12-20. [Indonesian] 
Utina R. 2012. Ecological Intelligence in Local Wisdom of Bajo Community Torosiaje Village Gorontalo Province. Proceedings of the $21^{\text {st }}$ National Conference And Seminar of Indonesia's Center for Environmental Studies September 2012. Mataram. [Indonesian] 